\title{
Some origins of cross-cultural psychiatry
}

\author{
ANA MARIA G. RAIMUNDO ODA \\ State University of Campinas, Brazil \\ CLAUDIO EDUARDO M. BANZATO \\ State University of Campinas, Brazil
}

PAULO DALGALARRONDO*

State University of Campinas, Brazil

The interface between insanity, race and culture was a challenging subject for some of the most influential nineteenth-century alienists. Our paper reviews some of the theoretical and clinical investigations of comparative psychiatry of this period. The idea that insanity was supposedly rare among 'primitive' people, e.g., Africans, American Natives and some Eastern populations, was repeatedly defended by prominent alienists. Associated with this notion, many authors believed that insanity tends to become more prevalent as civilization evolves. According to them, civilization had an unfavourable effect on insanity rates because it demanded a much higher degree of organization and mental production. Moreover, a greater degree of mental excitation would explain why insanity occurs more frequently in Europe than in the East, Africa or South America. Eventually, at the end of the nineteenth century, the coalition of crosscultural and neuropsychiatry produced a notion that the brain of the 'native' is more simple and crude than that of the civilized, and more vulnerable to the evil effects of civilized life. In conclusion, some ethnocentric bias and racial stereotypes still pervasive in contemporary psychiatry are identified and traced back to their historical origins.

Keywords: civilization; cross-cultural psychiatry; history; race; racism.

* Address for correspondence: Department of Medical Psychology and Psychiatry, Medical School - State University of Campinas (UNICAMP), CP 6111, 13083-970 Campinas, SP, Brazil. Email: pdalga@fcm.unicamp.br 


\section{Introduction}

During the last two centuries a number of clinical investigations and theoretical studies were carried out in order to explore the complex relation of mental disorder, race and culture. They ended up establishing a new field of knowledge, so-called cross-cultural psychiatry, also known as ethnopsychiatry (in the French-speaking countries), comparative, transcultural or, more recently, cultural psychiatry.

Some authors (e.g., Boroffka, 1988; Lauter, 1965) stated that the origins of cross-cultural psychiatry began with the works of Kraepelin (1904a, $1904 b$ ) in Java. It is an undisputed fact that even our current psychiatric nosography pays considerable tribute to Kraepelin (Berrios \& Hauser, 1995). Nonetheless, we do not endorse his views on the early history of cultural psychiatry. However important Kraepelinian work may be, it was not at all the beginning of cross-cultural psychiatry. Before him there was a body of theoretical and clinical work which tried to address the complexities of the relationship within psychiatry, mental disorders, race $^{1}$ and culture. Unless we study these predecessors carefully, we will not be able to understand how the net of present-day cultural psychiatry was woven from medical and social theories and discourses.

We must first take into account the social context of our subject. Although the first quarter of the nineteenth century was marked by some decrease in European colonialism (exemplified by the independence of most LatinAmerican nations), the following 75 years of that century testify to a marked expansion by Europeans and North Americans into previously unexplored territories. The need to expand the capitalist market and to control the sources of raw materials, the modernization of naval technology and the growing nationalist ideology in Europe are some of the reasons for the neocolonial growth observed (Fieldhouse, 1965).

Between 1875 and 1914 - a period called 'the age of empire' by Eric Hobsbawm (1989) - large parts of the world, especially Africa and Oceania, were claimed as territories owned by a few developed countries, and as such these lands were divided among them. The UK, France, Germany, Italy, the Netherlands, Belgium, USA and, to a lesser degree, Japan governed colonial empires directly, or maintained under their political and economic influence, vast areas of the globe. Such colonialist expansionism was a product of an era of intense competition among flourishing industrial economies, all of them aiming at opening up new markets and controlling essential raw materials, which would eventually make colonized countries dependent upon their colonizers (Hobsbawm, 1989). Therefore, during the nineteenth century, capitalist economies flourished internationally, determining a progressive expansion of economic transactions between developed, wealthy countries and undeveloped, poor ones. As a result, there was an increase in the exchanges between them, not only of goods and money, but also of people (Hobsbawm, 1975). 
Certainly, this new cycle of colonialism influenced the debate concerning the relationship between white/non-white, civilized/savage, Christian/nonChristian, reframing the sociological and political (and also psychiatric) discussion on the 'sociability of races and people'. In addition to neocolonial expansion, the abolition of slavery in the Americas also played an important role in this process.

\section{Civilization and insanity}

The idea that insanity, supposedly rare among 'primitive' people, tends to be more prevalent as civilization evolves was a trademark of alienism in the nineteenth century, thus showing the deep penetration and lasting influence of the Rousseaunian theses on social and medical thinking. ${ }^{2}$

Some of the most distinguished alienists and reformers of the century, such as Esquirol, Moreau de Tours, Griesinger, Krafft-Ebing, Hack Tuke and Lombroso, argued in favour of the idea that there was an intimate relation between civilization and mental illness and that the latter was actually rare among the so-called primitive people. Also, the belief that insanity could be reaching alarming levels in large European cities became a prevalent concern among nineteenth-century alienists (Esquirol, for example).

Esquirol, in his book Des Maladies mentales (1838), used the voyage reports of the German naturalist Alexander von Humboldt to endorse his ethnopsychiatric hypotheses. In his trip to South America, von Humboldt had been surprised by the absence of mental illnesses among the 'savages' (von Humboldt, 1816/1992). Esquirol asserted that the excesses of civilization - that is, disordered life, the abuse of alcoholic beverages, and excessive consanguine marriages (noticed, according to him, mainly in England) were reputed to be causes of the high frequency of insanity among European people. Thus, wherever civilization had not yet developed completely, insanity would be rare; for example, it was less likely to be found in China, Turkey, Spain and Mexico than in France.

Combining social reformism and Catholic morality, Esquirol associated the increase of mental illness with social disturbances, revolutions and abrupt changes of habits, customs and values. He speculated that mental illness would probably be more frequent in larger cities than in the countryside. Nevertheless, Esquirol did not rule out the possibility that this phenomenon could, in truth, be just a bias since the asylums were located in large cities and could therefore attract to the vicinity sick people in need of medical attention (Esquirol, 1838).

From December 1836 to October 1837 a disciple of Esquirol, Moreau de Tours, carried out an exploratory trip to Malta, Egypt and the Middle East, possibly the first 'ethnopsychiatric expedition'. Even taking into account the evidence that many of the mentally ill in these countries never reached the asylums he visited, as he wandered around villages and cities Moreau confirmed 
his belief that there were actually fewer insane people in these regions than in Europe. He attributed this finding to climatic and moral factors. According to Moreau (1843), civilization would favour the development of nervous afflictions,

because it [civilization] is a state of agitation, of continuous dislocation, of unceasing struggle between the one who leaves and the one who arrives, between the past and the future, a struggle in which all members of the social body participate more or less actively, each in his own sphere. ${ }^{3}$

In the second half of the nineteenth century, many of the French alienists interested in such questions would accept the idea that civilization, social agitation, change of habits and insanity were inseparable from modern life (see, for example, Meilhon, 1896).

Griesinger (1867/1964), an important theoretician and reformer of German alienism, was critical of the statistical methods available at that time for attributing the increase of mental illness to the advancement of the civilization process, but nevertheless asserted that some factors of modern life did undoubtedly favour the increasing frequency of mental illnesses. Griesinger stated quite overtly his social and moral beliefs, asserting that certain factors were decisive in explaining the increase in mental illness among civilized populations, for example, abandonment of simple customs and religious values, exaggerated physical and mental pleasures leading to unhinged passions, liberal education and increased numbers of illegitimate children. Nonetheless, like Esquirol, Griesinger was cautious and acknowledged the insurmountable methodological difficulties (i.e., lack of reliable statistics to support cross-cultural comparability) in solving the questions regarding the relationship between civilization and insanity.

Krafft-Ebing, in his Lehrbuch der Psychiatrie (1879), discussed in detail the relation between civilization and mental disorders. According to him, civilization would have a deleterious effect on mental health due to the overpopulation of the large cities and the consequent worsening of hygienic and moral conditions. Extreme poverty, dreadful living conditions, bad nutrition and wholly unhealthy working conditions in factories would result in a 'degenerated proletariat'. Moreover, he considered that the improper pursuit of riches and pleasures and the excess of bastard children are decisive factors in the increase of mental illnesses.

Furthermore, Krafft-Ebing examined in detail a thesis held by other alienists (Beuchelt, 1974): the allegation that, compared with primitive societies and their so-called 'natural people' (Naturvoelker), modern European societies of 'cultured people' or civilized people (Kulturvoelker) demanded from their citizens a much higher degree of organization and mental production. That is to say, in the struggle for survival in modern societies, the requirement for refined and advanced mental functioning was reputed to be one of the principal causes for becoming mentally and 
physically ill, which would particularly affect those individuals who were constitutionally vulnerable. On the other hand, in societies 'without culture' and 'without ethics', as Krafft-Ebing called them, man would hardly differ from animals. Thus, the lack of the expectations inherent in civilized life would supposedly protect him from madness.

Lombroso (1902), within Italian criminology (and related alienism), was even more emphatic, pointing out the maleficent effects of civilization and moral degeneration of modern times. According to him, civilization meant a higher risk of specific mental illnesses:

The progress of civilization expands necessities and desires in such an incommensurable way that the increase of well-being overstimulates the senses, inducing the alcoholics and the paralytics (cerebral syphilis) to commit pathological crimes and crimes against property and customs. This has greatly increased the number of people in houses of correction.

Within British alienism, Maudsley showed a more cautious position than his French and German colleagues. He thought that certain products of civilization such as railways and modern ships, which accelerate communication and improve the flow of information, potentially provide modern man with such versatility that they would be better equipped to deal with the difficulties of life, and would thus be more protected from the risk of becoming insane. On the other hand, Maudsley emphatically professed the typical morality of the Victorian ethos: the hard life, excessive labour, discipline, and rigid and authoritarian education were factors that would shield man from mental illness. If, in fact, they were seeing an increase in the number of insane people (and also criminals), modern ideas and practices - which would lead people to self-indulgence, lassitude, sexual excesses and the lack of sacrifice - would account for it (Maudsley, 1879/1979).

By the end of the nineteenth century, Hack Tuke (1894) - for a long time, editor-in-chief of the prestigious fournal of Mental Science - also discussed this theme in detail. Addressing the increasing rate of insanity in Ireland, Tuke argued that the principal causes of this increase were the rise in poverty, malnutrition and the growing use of alcoholic beverages and tea. Besides this, the loss of certain healthy elements (the 'strengths' of society, according to Tuke) in the emigration process to America would also contribute to a certain degeneration of the race. Consanguine marriages, supposedly more frequent in Ireland, further increased the frequency of insanity.

In the USA, George Beard, who had created the successful category 'neurasthenia' in his book American Nervousness: Its Causes and Consequences (1881), emphasized:

The chief and primary cause of this development and very rapid increase of nervousness is modern civilisation, which is distinguished from the ancient by these five characteristics: steam-power, the periodical press, the telegraph, the sciences, and the mental activity of women. 
It is evident that influential alienists of the time shared an unequivocal moralistic militancy, as well as the conviction that civilization generates insanity. Almost in unison, they attributed the moral degeneration associated with modern civilization to certain fundamental causes: the dissemination of physical and mental pleasures, agitated life style, loss of simple habits, excesses in sex life, liberal education, lack of discipline and order, in addition to a loss of respect for traditional and religious values,

In terms of medical care, the second half of the nineteenth century progressively witnessed the failure of Pinel's moral treatment and, consequently, a growing therapeutic nihilism (Ackerknecht, 1985). Within this context, theories regarding hereditary predisposition to insanity and the mental vulnerability of certain social groups were strongly reinforced (Sedgwick, 1981). For example, this vulnerability was imputed in the Irish and the 'Negroes' in the USA (Dain, 1964; Deutsch, 1944), the poor in general in Great Britain (Skultans, 1979), and the 'half-breed' in Brazil (Nina-Rodrigues, 1903). Moreover, from the end of the eighteenth century on, most alienists came to share the belief that excessive stimulation would damage the nervous system and result in insanity. ${ }^{4}$

Dr Robert Jones, President of the Psychology Section of the British Medical Association, stated in 1903 that the moral deterioration of civilized people, mainly those living in large European cities, was intimately related to the increase in the frequency of mental illness. This moral deterioration would be accompanied by the racial deterioration of the poor of these cities; alcohol abuse and syphilis would be key factors in this process, coupled with the daily stress related mainly to bad working conditions and poor housing of the working class.

\section{Insanity among 'primitive people'}

Between 1840 and 1850, important scientific periodicals appeared in France, England and the USA, helping psychiatry to establish itself as a legitimate medical discipline. Annales médico-psychologiques (from 1843), fournal of Mental Science (from 1850), and American Fournal of Insanity (from 1844) became, so to speak, official vehicles for alienism.

Moreau de Tours (1843), one of the founders of the Annales médicopsychologiques, published in the journal's inaugural issue the first detailed study on mental illnesses among 'exotic people'. As mentioned above, Moreau travelled in the eastern Mediterranean area in 1836-37. This gave him the opportunity to make detailed observations of the institutions for the insane in the countries he visited, as well as the people in them. He not only carried out surveys of these people, but also interviewed them and their attendants.

According to Moreau, insanity among eastern Mediterranean people was a phenomenon intimately related to unhappiness in love (chagrin d'amour), but first and foremost to the exaltation of religious feelings. After examining 
inmates from several asylums, he noticed, to his surprise, the scarcity of progressive general paralysis among them.

Within an evolutionist and parallelist perspective, well attuned to the Zeitgeist, Moreau suggested that from a medical and cultural point of view the East in the middle of the nineteenth century was similar to medieval Europe. He realized that Arabs and Turks used to confine only their aggressive and dangerous patients; the majority of the mentally ill tended to remain at home to be looked after by the family. Insanity in the East was considered to be a 'sacred evil', and many of the so-called 'Oriental saints' who wandered around the streets of Cairo or Constantinople were, in fact, insane. In spite of these differences in the recognition and destiny of the mentally ill, Moureau's personal experience indicated that insanity was indeed rarer in the East than in Europe, thus supporting Esquirol's thesis that modern civilization instigates madness.

In religious terms, Moreau contrasted the East, the natural home of Islam, passive and fatalistic, to the Christian West, active and enterprising. Just as the Western European was inclined to be ambitious and intellectual active, the Oriental tended to be resigned and passive, preferring the simple and immediate pleasures of material life in the warm climate. A point stressed time and again by Moreau was that the development of madness in the East would be strongly related to religious exaltation, frequently seen among Muslim people. The intensely emotional character of prayers, hymns and religious dances ('rotating' Dervishes would be an example) could quickly lead the believer into extreme religious trances and ecstatic states that would often result (eventually) in the 'disorganization of moral faculties' and consequent insanity.

Given the fact that mental illness, to Moreau, was basically a disorder of cerebral functions produced by a higher degree of mental excitation, it is understandable why insanity would naturally occur more frequently in Europe than in the East. According to him, the causes of insanity in the East were attributed mainly to climatic factors, to the physical constitution and to the moral organization of Eastern people, together with the influence of political and religious institutions. Thus, the hot climate would explain to some extent the apathetic, fatalistic and submissive constitution of the Oriental.

A decade after the publication of Moreau's study, another article appeared defending similar ideas. Winslow (1853) summarized the ethnopsychiatric observations of the superintendent of a psychiatric sanatorium in Bengal, India: Dr Thomas Wise. In his opinion, insanity in India was closely related to the harmful effects of the hot climate, the moon, mental endeavours and grief. Of particular interest was the fact that for Wise, as well as for Moreau, religious excesses and mystical fanaticism counted as important causal elements of mental disturbances among Hindus. It must also be pointed out that the opposition between Christianity and non-Christian religions, with the belittlement of the latter, played an important role in the ideological conflicts between the culture of the colonizer and that of the colonized. 
Many other accounts by travellers (missionaries, ships' officers and colonial doctors) appeared in the American Fournal of Insanity, from its first volume in 1844, supporting the idea of rarity of mental illness among 'primitive' people. The editor-in-chief, Dr Amariah Brigham (1798-1849), collected and organized these reports which repeatedly reached the same conclusions.

It was also widely believed that insanity was rare among African natives (Cinquez, in a letter to Brigham, 1845). Native people of the South Pacific would be also exempt from insanity. Capt. Wilkes, commander of the 'United States Exploring Expedition', reported that during all his voyages to the southern seas he had never seen a case of insanity, which would be, so to speak, a prerogative of civilized Western man (Brigham, 1845). Mental illness was supposed to be equally rare in China (letters from Mr Cushing, Dr McGowan and Rev. Williams to Brigham, 1847).

A striking example was provided by Dr Lillybridge from Virginia, USA, the doctor in charge of the transference of the Cherokee Indians to the Indian reserves between 1827 and 1829. Although he observed more than twenty thousand Indians, he denied ever seeing or being told about any case of insanity among them (Lillybridge \& Butler, 1845). Dr Butler, who was a medical missionary with the Cherokees for about 25 years, reported that, apart from witnessing occasional cases of mental confusion of organic origin in physically ill patients, he had never known of any case of insanity like those observed in Philadelphia's Mental Hospital (Lillybridge \& Butler, 1845). ${ }^{5}$

Finally, it is worth mentioning that the nineteenth-century expansion of English, French and Dutch neocolonialism was accompanied by the growing interest in the possibility of special mental illnesses among the native people of these colonies. Alienists in the colonies started to notice sharp contrasts between patients seen there and those previously seen in Europe (Wittkower and Price, 1980). These differences were increasingly reported in European psychiatric journals. Within this context, detailed descriptions of cases, apparently restricted to primitive people, originated what might be labelled as a 'psychiatry of the exotic' (Kua, 1991). These included amok (Ellis, 1893), and latah in Java (Ellis, 1897; Van Brero, 1895), myriath in Siberia (Tokarski, 1890) and koro among the Chinese in Java (Van Brero, 1897). Dubreuil and Wittkower (1974) wrote: 'Accounts of strange syndromes observed in conquered countries were reported by colonial and military doctors. Some were meticulous and could be considered the first ethnographic data of psychiatric anthropology.'

\section{Contact with civilization increases mental illness among 'primitive' people}

Somewhat paradoxically, the century in which there was a sound European expansion was also noted for the idea that civilization had a harmful effect on the mental health of 'primitive man'. The introduction of alcohol into native 
culture was reputed to be the main destructive element provided by modern civilization. This, however, seems to be a notion much older than alienism itself. For example, a forerunner of North American alienism, the surgeon Dr Benjamin Rush (1785/1943), wrote an extensive paper denouncing alcohol as one of the main destructive factors among the indigenous tribes conquered by the North American colonizers. Most nineteenth-century alienists claimed that the frequency of mental illnesses depended on the degree of intimacy between native and civilized, and they were positively associated (Furnari, 1846; Greenlees, 1885; Hummer, 1913; Nina-Rodrigues, 1903). French alienist Furnari, for instance, postulated in 1845 that the 'torpor of the intellectual faculties of the native Muslim, fomented by despotic governments, nomad life and alcoholic temperance' would protect them from mental illness. He remarked, however, that mental illness tended to increase as the native became more Western-like, particularly because of the harmful effects of alcohol (at that time the drinking of absinthe was widespread among the natives brought into the French colonial army).

It is also worth mentioning that the contact between European colonizers and indigenous people, apart from implying economic, political and cultural submission, was frequently accompanied by severe epidemics of infectious illnesses such as tuberculosis, syphilis, smallpox and measles. In a way, these epidemics adduced further evidence in favour of the Rousseaunian notion that civilization is harmful to the health of 'primitive man'.

\section{Cross-cultural psychiatry meets neuropsychiatry}

At the end of the nineteenth century, attuned to the organicist and evolutionistic Zeitgeist, the idea that the brain of the native was more primitive than the brain of the European and resembled that of a child became prevalent (Da Rocha, 1898; Greenlees, 1885; Grieve, 1880; Meilhon, 1896). Meilhon, for example, attributed impulsive behaviour - according to him, frequent among Muslims in North Africa - to an innate cerebral inferiority, inherent to the race, making them equal to most 'inferior degenerates' of Europe. Moreover, in America some authors alleged that Negroes would have a brain anatomically more primitive than that of Whites. The work of Bean (1906) in the USA is, in this sense, paradigmatic. He said that Negroes had a brain with diminished frontal lobes, explaining why they would have:

more developed inferior mental faculties such as smell, sight, manual ability, corporeal sense and melody, while whites, on the other hand, would have developed higher mental faculties such as self-control, ambition, ethical and aesthetic sense and reason.

In Brazil, the alienist Franco Da Rocha (1898) similarly asserted that the Negro, like a child, tends to manifest psychopathology through motor symptoms and dementia denoting a more primitive cerebral organization. By 
the end of the nineteenth century, the combination of a prestigious organic psychiatry with European colonial racism and ideologies of the dominant class, transformed the savage and the Negro from an exotic and simplistic personality into someone with a cruder and more primitive brain.

At the turn of the century, the idea that the indigenous native was especially vulnerable to the effects of civilization - given that his more primitive brain would not support the damaging effects of a more evolved type of society - predominated among North and South American alienists. In the USA many authors (the most notable example is Jarvis, 1844, 1852) tried to show that the supposed increase of mental illnesses among Negroes after the abolition of slavery was related to the lack of mental preparation of AfroAmericans for life in a 'free and civilized' society. In South America, the Brazilian Nina-Rodrigues (1903) also promulgated the idea that civilized life would be prejudicial to Africans and their descendants, 'a race accustomed to centuries of life in African jungles'.

This tendency in cross-cultural psychiatry, even though openly racist and ethnocentric, was - surprisingly - defended until the middle of the twentieth century, primarily by some psychiatrists involved in the colonies in Africa. Among those were, for example, Porot (1935), who formulated the hypothesis of 'diencephalic predominance' in the Muslim Berbers of Algeria (see also Porot and Arrii, 1932). Recently, two historical revisions (Bégué, 1993; McCulloch, 1993) attempted to show how this 'neuro-ethnopsychiatric' version served as ideological foundations for discriminatory policies of neocolonialism in Africa.

\section{Cultural psychiatry and its contemporary trends}

In a comprehensive and critical review published a decade ago, Littlewood (1993) pointed out that several issues related to colonial heritage and racism are still to be found in contemporary psychiatry, both in theory and practice. For instance, in the 1950s at the end of the colonial period, opposite stances were taken by two authors: J. C. Carothers and F. Fanon. Carothers, a British colonial psychiatrist, regarded the African as similar to a child or to a primitive, ancient form of human being. ${ }^{6}$ In 1951 he put forward a theory about the hypofrontal brain of the native of Kenya, pointing out 'a striking resemblance between African thinking and that of leucotomized Europeans'. In 1954 Carothers wrote: ' $[T]$ he thinking of the African is Childlike, that he lacks the capacity for reflection and foresight, that emotion rather than intellect governs his behaviour, that he cannot withstand anxiety, and that he displays little capacity to adapt to change.' At the very end of the colonial cycle, he epitomized most stereotypes and forms of racial prejudices produced by colonial psychiatry.

Frantz Fanon (1925-61), an Afro-Caribbean psychiatrist (and later political activist) born in Martinique, was one of the first authors to analyse the relationship between colonial subjugation, racism and psychopathology in a radically different way. In his first work, Peau noire, masques blancs, published 
in 1952, he claimed that the European was used to seeing the 'Negro' as a kind of 'phobogenic object', a perception of 'the Black' (and the insane) as some sort of undifferentiated 'Other' (Littlewood and Lipsedge, 1982). In addition, Fanon (1952) pointed out that the 'Negro' symbolized 'the Biological', a cluster of stereotypes related to sexual instincts, genital potency, violence and lack of any morality. Later, in Les Damnés de la terre (1961), Fanon stated that violence and prejudice characterized the binary opposition of colonizer and colonized, which heavily influenced most of the intellectual works on African psychology and psychopathology.

Contemporarily, the perceived high prevalence of schizophrenia and other psychoses among people of West Indian origin in the UK, as well as among non-White minorities in other countries (Maoris in New Zealand, Native Australians, and Afro-Americans in the USA) brought up some rather polemic social and epidemiological issues (Littlewood, 1993). First, it is still controversial whether such 'epidemiological data' are consistent or not. One has to rule out the possibility that they are mere by-products of a number of diagnostic biases, due to cultural or linguistic barriers, ethnocentrism or even racism. Littlewood (1993) pointed out several hypotheses suggested by different authors: inaccurate population figures, psychological consequences of racial oppression, Black unemployment, minority attitudes, cultural conflict and resistance and even genetic or biological vulnerability (such as obstetrical disadvantages, for example). Moreover, in the UK and the USA a number of studies have shown that non-White (especially Black) patients are more likely to be involuntarily hospitalized, to receive more physical treatment and less psychotherapy or counselling. They are also more likely to be brought to psychiatric facilities by the police and to receive depot antipsychotic medication (Bhugra \& Bhui, 1999; Littlewood, 1993).

Littlewood (1993) claimed that even cross-cultural psychiatry has been insensitive regarding issues specifically connected to West Indians, Africans and Afro-Americans, such as 'minorities' construction of selfhood, understanding of illness, patterns of psychological adjustment, recourse to mental health agencies and attitude to professional medicine in general'. This seems to indicate that low cultural sensitiveness to minorities and ethnic groups continue to be the rule, even in research related to cross-cultural psychiatry.

Thus, what seems to be at stake here is not only whether psychiatry has been historically racist in its theoretical assumptions, but also if it still continues to be so in its current diagnostic procedures and clinical practices (Littlewood, 1993).

\section{Conclusions}

Apart from the political and economic aspects of colonialism, its broad cultural consequences, especially for what is now called 'cultural psychiatry', should be emphasized: the whole world was to become dominated by 
images, ideas and aspirations of developed Western countries. Within the period in question, the élite of the colonies became Westernized. Interestingly, at the same time Europeans and North Americans started seeing the people from the colonized lands as inferior, weak, retarded or unable to progress (Hobsbawm, 1989).

In this context, scientific studies of colonial natives, their habits, illnesses and idiosyncrasies may also be seen as a strategy for consolidating the colonizers' political and economical dominance, as it was obviously necessary to know the natural resources as well as the way of life of the inhabitants of such lands. According to the postulates of 'Social Darwinism' (free competition and survival of the fittest) differences among people simply amounted to natural inequalities. The European white man was seen as the apex of the hierarchical scale of the human races, the norm and the model of perfection, a belief endorsed by most scientists in the second half of the nineteenth century. Such superiority was self-evident for the creators and supporters of this theory, as they themselves were assumed to be the occupants of the best place in the evolutionary scale (Gould, 1981).

The adjectives 'natural', 'innate' and 'biological' used to accompany the definitions given by the scientific consensus, guaranteeing the primacy of the Western white man. This widely shared cultural belief was built into a truly scientific paradigm, helping to shape a system of ideas which was later to be called 'scientific racism' and denounced as a typical product of the nineteenth century that justified the exploitation of the so-called 'inferior' persons by those who thought of themselves 'superior'.

It remains an open question the extent to which psychiatric institutions and clinical practice followed general, unspecific ethnocentric and racial prejudices against non-Whites and members of the urban underclasses ('alcoholics and petty criminals, the unemployed, the rootless, etc.') or whether psychiatric theory and practice created a specific set of racial, ethnocentric and class-related theories and practices that supported (and probably still continue to support) general racial and ethnic stereotypes and prejudices (Bhugra \& Bhui, 1999; Littlewood, 1993).

The history of cross-cultural research in psychiatry outlined in this article reveals a complex set of interwoven ideas and practices, the knowledge of which may well be relevant for the present and future of general psychiatry. One may hope, indeed, that it might contribute to the development of a truly non-racist and culturally sensitive psychiatry.

\section{Notes}

1. Regarding race and racism in science and in psychiatry, a remarkable work that treats this question in depth is Stephen J. Gould's The Mismeasure of Man (1981). And in 1993, Laurence Kirmayer organized a symposium on 'Racism and Psychiatry', which was published in Transcultural Psychiatric Research Review, 30 (3). 
2. In the nineteenth century, the influence of Jean Jacques Rousseau with his innocent savage' thesis on medical thinking and alienism was very important. According to Rousseau, man in his natural state is self-sufficient, that is, an independent individual who, by means of self-esteem (amour de sol), and driven by natural necessities, would maintain and care for himself. The inequality among men would be caused by that sort of love for himself (amour propre) which goes way beyond self-esteem, that is, the sense of superiority and the desire for dominating other men. The end products of such a process would be private property, power, envy, and eventually war (Rousseau, 1755/1973).

3. All translations are ours.

4. This provided the rationale for isolating the mentally ill. Actually, this belief spread so widely that isolation would later become simply the 'natural procedure' to be adopted towards cure (Sedgwick, 1981).

5. Dr T. W. McDowall (1897), in his Presidential Address to the British MedicoPsychological Association on 29 July, started a kind of reaction to this notion. He pointed out that: 'Whilst most of my correspondents state that lunatics in India are very rare, others strongly insist that there are crowds of them, and that they are got rid of in a variety of objectionable ways.'

6. He also published such opinions in a monograph commissioned(!) by the World Health Organisation (Carothers, 1953).

\section{References}

Ackerknecht, E. H. (1985) Kurze Geschichte der Psychiatrie (Stuttgart: Ferdinand Enke).

Bean, R. B. (1906) Some racial peculiarities of the Negro brain. American Fournal of Anatomy, 5, 353-415.

Beard, G. M. (1881) American Nervousness: Its Causes and Consequences (New York: G.P. Putnam's Sons).

Bégué, J. M. (1993) Un siègle de psychiatrie française en Algerie (1830-1939): contribuition à l'histoire de l'ethnopsychiatrie. L'information psychiatrique, 1, 67-72

Berrios, G. E. and Hauser, R. (1995) Kraepelin. In G. Berrios and R. Porter (eds), A History of Clinical Psychiatry (London/New Brunswick: Athlone Press).

Beuchelt, E. (1974) Ideengeschichte der Völkerpsychologie (Meisenheim am Glan: Anton Hain).

Bhugra, D. and Bhui, K. (1999) Racism in psychiatry: paradigm lost, paradigm regained. International Review of Psychiatry, 11, 236-43.

Boroffka, A. (1988) Emil Kraepelin (1856-1926) and transcultural psychiatry: a historical note. Transcultural Psychiatric Research Review, 25, 236-9.

Brigham, A. (1845). Letters from Cinquez and Captain Wilkes (Exemption of the South Sea Islanders from Insanity). American fournal of Insanity, 2, 285.

Brigham, A. (1847). Letter from Rev. Williams (About insanity in China) and letters from Mr. Cushing and Dr. McGowan. American fournal of Insanity, 4, 74-5.

Carothers, J. C. (1951) Frontal lobe function and the African. Fournal of Mental Science, 97, $12-48$.

Carothers, J. C. (1953). The African Mind in Health and Disease (Geneva: WHO).

Carothers, J. C. (1954) The Psychology of Mau Mau (Nairobi: Government Printer).

Dain, N. (1964) Concepts of Insanity in the United States (New Brunswick: Rutgers University Press).

Da Rocha, F. (1898) Bemerkungen über das Vorkommen des Irreseins bei den Negern. Allgemeine Zeitschrift für Psychiatrie und psychisch-gerichtliche Medizin, 55, 133-50.

Deutsch, A. (1944) The first U.S. census of the insane (1840) and its use as pro-slavery propaganda. Bulletin of the History of Medicine, 15, 469-82. 
Dubreuil, G. and Wittkower E. D. (1974) Psychiatric anthropology, transcultural psychiatry: the past. Transcultural Psychiatric Research Review, 11, 7-11.

Ellis, G. (1893) The amok of the Malays. Fournal of Mental Science, 39, 325-38.

Ellis, G. (1897) Latah: a mental malady of the Malays. Fournal of Mental Science, 43, 32-40.

Esquirol, J. E. D. (1838) Die Geisteskrankheiten in Beziehung zur Medizin und Staatsarzneikunde (Berlin: Verlag der Voss'schen Buchhandlung); originally published as: Des Maladies mentales, considerées sous les rapports médical, higiénique et médico-légale, 1838.

Fanon, F. (1952) Peau noire, masques blancs (Paris: Editions du Seuil); English translation: Black Skin, White Masks (Harmondsworth: Peguin, 1967).

Fanon, F. (1961) Les Damnés de la terre (Paris: François Maspéro); English translation: The Wretched of the Earth (London: MacGibbon \& Kee, 1963).

Fieldhouse, D. K. (1965) Die Kolonialreiche seit dem 18. Fahrhundert (Frankfurt am Main: Fischer Bücherei).

Furnari, A. (1846) Voyage médical dans l'Afrique septentrionale. Annales médico-psychologiques, 8, 349-61.

Gould, S. J. (1981) The Mismeasure of Man (New York: W. W. Norton).

Greenlees, D. (1885) Insanity among the natives of South Africa. Fournal of Mental Science, $41,71-8$.

Griesinger, W. (1867/1964) Die Pathologie und Therapie der psychischen Krankheiten für Ärzte und Studirende (Amsterdam: E. J. Bonset).

Grieve, R. (1880) Insanity in British Guiana. Fournal of Mental Science, 26, 370-4.

Hobsbawm, E. J. (1975). The Age of Capital: 1848-1875 (London: Weidenfeld and Nicolson).

Hobsbawm, E. J. (1989) The Age of Empire: 1875-1914 (New York: Vintage Books).

Hummer, H. R. (1913) Insanity among the Indians. American fournal of Insanity, 69, 615-23.

Jarvis, E. (1844) Insanity among the colored population of the free states I. American fournal of Medical Science, 7, 71-83.

Jarvis, E. (1852) Insanity among the colored population of the free states II. American fournal of Insanity, 8, 268-82.

Jones, R. (1903) President's address on 'The development of insanity in regard to civilsation'. Fournal of Mental Science, 49, 776-7.

Kraepelin, E. (1904a) Vergleichende Psychiatrie. Centralblatt für Nervenheilkunde und Psychiatrie, 15, 433-7.

Kraepelin, E. (1904b) Psychiatrisches aus Java. Allgemeine Zeitschrift für Psychiatrie und psychischgerichtliche Medizin, 61, 882-4.

Krafft-Ebing, R. von (1879) Lehrbuch der Psychiatrie auf klinischer Grundlage für practische Ärzte und Studirende (Stuttgart: Ferdinand Enke).

Kua, E. H. (1991) Amok in nineteenth-century British Malaya history. History of Psychiatry, 3, 429-36.

Lauter, H. (1965) Kraepelins Bedeutung für die Kulturpsychiatrie. Transcultural Psychiatric Research Review, 2, 9-12.

Lillybridge and Butler [initials not given] (1845) Exemption of the Cherokee Indians and Africans from insanity (letters to Dr. Brigham). American fournal of Insanity, 2, 287-8.

Littlewood, R. (1993) Ideology, camouflage or contingency? Racism in British Psychiatry. Transcultural Psychiatric Research Review, 30, 243-90.

Littlewood, L. and Lipsedge, M. (1982) Aliens and Alienists: Ethnic Minorities and Psychiatry (Harmondsworth: Penguin).

Lombroso, C. (1902) Die Ursachen und Bekämpfung des Verbrechens (Berlin: Hugo Bermühler).

Maudsley, H. (1879/1979) The Pathology of Mind: A Study of its Distempers, Deformities and Disorders (London: Julian Friedmann Publishers). 
McCulloch, J. (1993) The empire's new clothes: ethnopsychiatry in colonial Africa. History of the Human Sciences, 6, 35-52.

McDowall, T. W. (1897) The insane in India and their treatment. Fournal of Mental Science, 43, 683-703.

Meilhon [initials not given] (1896) L'aliénation mentale chez les Arabes: études de nosologie comparée. Annales médico-psychologiques, 3, 17-32, 177-207, 364-77.

Moreau de Tours, J. (1843) Recherches sur les aliénés en orient: Notes sur les établissements qui leur sont consacrés a Malte (Ile de), au Caire (Égypte), a Smyrne (Asie-Mineure), a Constantinople (Turquie). Annales médico-psychologiques, 1, 103-32.

Nina-Rodrigues, R. (1903) La paranoïa chez les nègres. Archives d'anthropologie criminelle, de criminologie et de psychologie normale et pathologieque, 118, 609-55, 689-714.

Porot, A. (1918) Notes de psychiatrie musulmane. Annales médico-psychologiques, 4, 225-40.

Porot, A. and Arrii, D. C. (1932) L'impulsivité criminelle chez l'indigene algérien. Annales médico-psychologiques, 90, 588-611.

Rousseau, J. J. (1755/1973) Discurso sobre a origem e os fundamentos da desigualdade entre os homens (São Paulo: Abril Cultural Ed.).

Rush, B. (1785/1943) An inquiry into the effects of ardent spirits upon the human body and mind with an account of the means of preventing and the remedies for curing them. Quarterly fournal of Studies on Alcohol, 4, 321-41.

Sedgwick, P. (1981) Michel Foucault: the anti-history of psychiatry. Psychological Medicine, 11, $235-48$.

Skultans, V. (1979) English Madness: Ideas on Insanity 1580-1890 (London, Boston and Henley: Routledge \& Kegan Paul).

Tokarski, A. (1890) Meriatschenje und maladie des tics convulsifs. Neurologisches Centralblatt, $21,662-3$.

Tuke, H. (1894) Increase of insanity in Ireland. Fournal of Mental Science, 40, 549-61.

Van Brero, P. C. J. (1895) Latah. Journal of Mental Science, 41, 537-8.

Van Brero, P. C. J. (1897) Koro, eine eigenthümliche Zwangsvorstellung. Allgemeine Zeitschrift für Psychiatrie und psychisch-gerichtliche Medizin, 53, 569-73.

von Humboldt, A. (1816/1992) Die Wiederentdeckung der Neuen Welt (München: Carl Hanser).

Winslow, F. (1853) Insanity in India. Fournal of Psychological Medicine and Mental Pathology, 6, 356-67.

Wittkower, E. D. and Price, R. H. (1980) Geschichte und Entwicklung der transkulturellen Psychiatrie. In W. M. Pfeiffer and W. Schoene (eds), Psychopathologie im Kulturvergleich (Stuttgart: Ferdinand Enke). 